\title{
Customers' Attitude towards General Insurance - A Factor Analysis Approach
}

\author{
Ms. Tnr. Kavitha, ${ }^{1}$ Dr. A. Latha, ${ }^{2}$ Ms. S.Jamuna. ${ }^{3}$ \\ 1, 3 (Department of Management Science, Erode Sengunthar Engineering College, Erode, India.) \\ ${ }^{2}$ (Department of Commerce, LRG Government Arts College for Women, Tirupur, India.)
}

\begin{abstract}
With over a billion people, India is fast becoming a global economic power. With a relatively youthful population, India will become an attractive insurance market over the next decades. This paper examines the customer attitude towards the General Insurance. A study has been conducted at Erode district with the sample of 750 respondents to find out the influencing factor of the policy holders in the study area. In this context, the respondents' opinion on the various related statements were collected with a 5 point scaling. Factor analysis, an important multivariate technique has used to reduce the large number of factors in a small group of factors. 25 factors which are considered to be the different type of policy holders conscious. This study helps to find out the various customers which are having different expectation from the General Insurance Companies in the study area.
\end{abstract}

Keywords: Buying Behavior, General Insurance, Global Economic Power, Influencing factor, Insurance Market.

\section{Introduction}

Insurance is defined as the simple mechanism of some people who are exposed to the same level of risks of suffering destruction of damage to their properties, that are likely to be caused by perils like accident, fire, floods earthquakes, etc., coming together and agreeing to share the loss sustained any one of the members'; that is, the loss of one or more members is spread among all. Risk is uncertainty of a financial loss. It should not be confused with the chance of loss which is the probable number of losses out of a given number of exposures. It should not be confused with peril which is defined as the cause of loss or with hazard which is a condition that may increase the chance of loss. Finally, risk must not be confused with loss itself which is the unintentional decline in or disappearance of value arising from a contingency. Wherever there is uncertainty with respect to a probable loss there is risk.

Every risk involves the loss of one kind or the other. The function of insurance is to spread the loss over a large number of persons who have agreed to co-operate with each other at the time of loss. The risk cannot be averted but loss occurring due to a certain risk can be distributed amongst the agreed persons. They have agreed to share the loss because the chances of loss, i.e., the time and amount payables to a person are not known. Any of them may suffer loss due to a given risk, so, the rest of the persons who have agreed will share the loss. The larger the number of such persons, the easier the process of distribution of loss. In fact, the loss is shared by them by payment of premium which is calculated on the probability of loss. In olden times the contribution by the persons was made at the time of loss. However, now that this activity is organised, the insurance companies collect the contributions in the form of premium even at the stage of agreeing to share the loss. The insurance is also defined as a social device to accumulate funds to meet the uncertain losses arising through a certain risk to a person insured against the risk.

\section{Changing Scenario of General Insurance Industry}

The General Insurance Sector dominated by General Insurance Corporation (GIC) and its four subsidiaries since nationalization of insurance, has started looking different now. The major happenings in the last few years of privatization can be summarized as below:

- Functional autonomy of subsidiaries of GIC has been granted.

- GIC has been instructed to stop writing direct business and act as Indian reinsure.

- IRDA has finalized various guidelines and regulations.

- Competition was reintroduced in 2000 with the licensing of the first private company. Large number of new entrants in the private sector is already operational.

- The intense competition brought about by deregulation has encouraged the industry to innovate in all areas, from underwriting, marketing, policyholder servicing, and so on.

- Aggressive marketing strategies by private sector insurers have buoyed consumer awareness of risk and expanded the markets for products. 
- Competition in a deregulated environment has allowed market forces to set premiums that are appropriate for exposures and push insurers to differentiate their products and services.

- Innovations in distribution and use of information technology have followed as public and private insurers compete to market their products.

- Allowing insurers to issue their own policy wordings w.e.f. April 1, 2008, and set their own rates w.e.f. Jan. 1, 2007 have enabled insurers to tailor products to meet client needs.

- So, the private sector was allowed into insurance business in 2000. However, foreign ownership was restricted not to exceed 26 per cent of foreign investment. Table 1.1 reveals that six companies from the public sector and 15 companies from the private sector have already entered into general insurance business in India. The increasing demand and novelty of business opportunities in the insurance market lured more and more players to enter into this field.

TABLE 1

List of General Insurance Companies in India

\begin{tabular}{|c|l|}
\hline S.No. & Name of the Company \\
\hline 1. & The Oriental Insurance Company Limited \\
\hline 2. & The New India Assurance Company Limited \\
\hline 3. & National Insurance Company Limited \\
\hline 4. & United India Insurance Company Limited \\
\hline 5. & Agriculture Insurance Company of India Limited \\
\hline 6. & Export Credit Guarantee Corporation Limited \\
\hline 7. & Royal Sundram Alliance Insurance Company Limited \\
\hline 8. & Reliance General Insurance Company Limited \\
\hline 9. & IFFCO Tokio General Insurance Company Limited \\
\hline 10. & TATA AIG General Insurance Company Limited \\
\hline 11. & Bajaj Allianz General Insurance Company Limited \\
\hline 12. & ICICI Lombard General Insurance Company Limited \\
\hline 13. & Appolo DKV Health Insurance Company Limited \\
\hline 14. & Future General India Insurance Company Limited \\
\hline 15. & Universal Sompo General Insurance Company Limited \\
\hline 16. & Star Health and Allied Insurance Company Limited \\
\hline 17. & Cholamandalam General Insurance Company Limited \\
\hline 18. & HDFC-Chubb General Insurance Company Limited \\
\hline 19. & Shri Ram General Insurance Company Limited \\
\hline 20. & Bharti Axa General Insurance Company Limited \\
\hline 21. & Raheja QBE General Insurance Company Limited \\
\hline
\end{tabular}

Source: www.irdaindia.org

\section{Indian Scenario}

The insurance sector in India has come a full circle from being an open competitive market to nationalization and back to a liberalized market again. Tracing the developments in the Indian insurance sector reveals the 360 degree turn witnessed over a period of almost two centuries. Younger people are insuring themselves. The average age of an insured person is now 33, down from 37 five years ago. Indians are insuring more, the average sum assured is now three to five times the LIC's average of Rs. 83,000 per policy. Agents are being trained to understand the needs of a client and then suggest the best policy that meets the client's needs, rather than just sell anything. Additional benefits can be bought in the form of riders as cover against deadly disease, surgeries and disability due to accident. The thrust is now on pension plans because life expectancy is going up and only $10 \%$ of population has pension cover.

\section{Review Of Literature}

Gobi S. and Parthasarathy R (2011) in their paper suggested that India's tryst with health insurance program goes back to the late 1940s and early 1950s when the civil servants (Central Government Health Scheme) and formal sector workers (Employees' State Insurance Scheme) were enrolled into a contributory but heavily subsidized health insurance programs. As part of liberalization of the economy since the early 1990s, the government opened up the insurance sector (including health insurance) to private sector participation in the year 1999. This development had thrown open the possibility for higher income groups to access quality care from private tertiary care facilities. As part of liberalization of the economy since the early 1990s, the government opened up the insurance sector (including health insurance) to private sector participation in the year 1999. This development had thrown open the possibility for higher income groups to access quality care 
from private tertiary care facilities. India is a low-income country with $26 \%$ population living below the poverty line, and 35\% illiterate population with skewed health risks. Insurance is limited to only a small proportion of people in the organized sector covering less than $10 \%$ of the total population. Currently, there no mechanism or infrastructure for collecting mandatory premium among the large scale informal sector.

Sharma Aparajita (2011) in her study aims to develop the managerial competency framework for the middle level managers of the general insurance sector in India. Secondary research provides the overview of existing generic competency models. The need was observed for a competency based framework in the insurance sector in India. Survey was conducted among ninety eight middle level managers of the public and private sector general insurance companies. The results revealed the fourteen managerial competencies: analytical skills, communication skills, creativity, decision-making, ability to delegate, flexibility, initiative, interpersonal skills, job knowledge, leadership, managerial skills, ability to motivate, ability to plan and team management. Job knowledge, managerial skills, were the most important skills. Other important skills were communication skill, inter-personal skill and team management.

Tarek Abd Elhamid Ahmed Taha, Yusnidah Ibrahim and Mohd Sobri Minai (2011) in their paper explained that, Loss reserve is one of the most important indicators that have many important and strategic decisions applications, such as rate making decisions, underwriting decisions, investment decision and corporate planning. The aim of this study is to identify the reliable time series forecasting model to forecast loss reserve estimates of Egyptian general insurance companies. Exponential smoothing model, Box-Jenkins analysis and time series regression model are applied on actual reported loss reserves data for general insurance sector for the period 1986 to 2006 and their accuracy are compared based on several error measures. The series from 1986 to 2001 are used for the estimations process and the remaining observations are used to evaluate the models as outside sample data. Exponential smoothing technique in all steps-ahead is identified as the best forecasting technique to Egyptian general insurance sector.

Pascale Turquet (2012) in his study found that for a number of years, the Dutch, German and French health insurance systems have been attempting to contain costs and diversify their sources of finance, which traditionally have come mainly from social contributions. Diversification may involve broader-based public finance, as well as greater recourse to private resources and operators. In the case of the Netherlands and Germany, the reforms go hand in hand with efforts to introduce competition between health insurance bodies. In France, private complementary insurance has become indispensable for adequate access to health care. However, these measures have repercussions for redistribution, which social assistance programmes have difficulty in addressing.

Srivastava, Samir K. and Ray, Avishek (2012) in their paper determines a set of marketing, financial and operational variables to predict benchmark financial strength of general insurance firms in India. It incorporates qualitative inputs from practicing managers and industry experts before carrying out quantitative modeling and analysis. We collect, compile and analyze the key financial, operational and business data of eight Indian insurance firms. The NAIC IRIS ratios method was used to obtain an initial risk classification. Linear regression and logit techniques were thereafter applied to estimate the significant factors (direction-wise and magnitude-wise) which influence insurer solvency. The results suggest that the factors that most significantly influence Indian non-life insurers are lines of business, the firm's market share, the premium growth rate, the underwriting performance and the claims incurred. Further, the factors which have the strongest effect are market share, change in inflation rate, firm size, lines of business and claims incurred. The paper provides insurers with easy-to-use operational and marketing indicators to benchmark their solvency risk. It will lead to competitive goal setting for continuous improvement. Estimation of appropriate market/economic parameters can be a useful input for regulators.

Vipin Saxena, Deepa Raj, and Vishal Verma (2012) in their paper attempt to unified Modeling Language known as UML is widely accepted around the globe as an object oriented modeling language which is used to construct the software designs. It is independent to the object-oriented programming languages and designed UML models can be easily implemented by any object-oriented programming language. In the present paper, UML model is proposed for the Vehicle Insurance Policy System (VIPS). A real case study of BAJAJ Company of India is considered and proposed model is applicable for all the types of the vehicles available in the world. UML class, sequence and activity diagrams are designed and the model has also been validated by performing several queries on the designed sample database.

\section{Statement Of The Problem}

In our country, the General Insurance companies, part of financial sector, are expected to show profits, though they are service-oriented organisations. The days are gone, when the General Insurance companies were set up with an exclusive motto of "service" instead of profit. The recent economic reforms urge the General Insurance Companies to introduce various insurance products in order to make profits by directing the schemes at target group of customers. The need for development of various insurance schemes is thus once again recognized and it will now be possible to introduce a variety of need based various insurance products in our 
own market, similar to those in the overseas markets. This study will help the Public and Private Insurance Companies to analyse its performance and to take corrective measures in the sphere of various Insurance products.

\section{Objectives Of The Study}

The study has the following objective.

- Building a model for the determination of factors that influence the policy holders to select the general insurance company for taking insurance policy.

\section{Database And Research Methodology}

Based on the research problem, the approach of this research has been divided into the primary method of data collection, analysis of data and conclusions. It involves the generation of data in the quantitative form, which can be subjected to rigorous quantitative analysis so as to infer characteristics or relationships. This design is used to identify the factors that affect the mindset of the individuals while utilizing the services offered by the General Insurance Companies. The factors that were identified and studied across the different satisfaction factors are mentioned in the Table 1.

TABLE 2

Factors induce to take policies in General insurance.

\begin{tabular}{|l|l|}
\hline No. & \multicolumn{1}{|c|}{ Factors } \\
\hline X1 & Courtesy of staff \\
\hline X2 & Product Price \\
\hline X3 & Officers / Agents are easily locatable \\
\hline X4 & Reminder for renewal of policy \\
\hline X5 & Response time \\
\hline X6 & Speed in Claim settlement \\
\hline X7 & Knowledge of the person dealing with you \\
\hline X8 & Product type \\
\hline X9 & Attitude of Surveyor \\
\hline X10 & Office appearance \\
\hline X11 & Motivation given by the officials to buy the policy \\
\hline X12 & Guidance / help at the time of purchasing the policy \\
\hline X13 & Promptness in issuing the policy \\
\hline X14 & Contacts by the development Officers/Agents after issuing the policy \\
\hline X15 & Development officer's attitude in helping the policy holder at the time of making claims \\
\hline X16 & Agent's attitude in guiding the claim settlement \\
\hline X17 & Company's attitude in settling claims \\
\hline X18 & Amount settled by the company (relative worth of the amount) \\
\hline X19 & Moral support \\
\hline X20 & Bonus for next premium payment \\
\hline X21 & Convenient Service \\
\hline X22 & Transparent of the Policies \\
\hline X23 & Claim Settlement Percentage \\
\hline X24 & Benefits associated with policy \\
\hline X25 & Cover more services \\
\hline
\end{tabular}

The conclusive research in the form of a descriptive cross-sectional survey was undertaken to determine the perceptual importance of the above mentioned factors in the mindset of customers. The primary research was conducted through a structured questionnaire. This structured questionnaire included closed-ended questions regarding the above mentioned factors on a 5 point semantic differential scale. Since there are too many factors that are identified in every segment, factor analysis, commonly referred to as a data reduction technique, is being used to identify some of the major areas that hold importance in the mindset of policy holders. In a more general way, it is a set of techniques, which, by analyzing correlations between variables, reduces their number into few factors, which explain much of the original data more economically. These could, in turn, be considered as strategic areas that require attention by the General Insurance companies. A single structured questionnaire was framed to collect data from the policy holders. 
Customers' Attitude Towards General Insurance - A Factor Analysis Approach

\section{Data Analysis}

Above twenty five factors which are influencing the policy holders to take policies in general insurance have been identified. Those factors are analyzed by the Simple percentage Analysis are as follows.

TABLE 3

Level of satisfaction or the factors induce for selecting the product in General insurance policies

\begin{tabular}{|c|c|c|c|c|c|c|}
\hline S.No. & Factors & HS & $\mathbf{S}$ & $\mathbf{N}$ & DS & HDS \\
\hline 1 & Courtesy of staff & $\begin{array}{c}225 \\
(30.0)\end{array}$ & $\begin{array}{c}305 \\
(40.7)\end{array}$ & $\begin{array}{c}116 \\
(15.5)\end{array}$ & $\begin{array}{c}64 \\
(8.5)\end{array}$ & $\begin{array}{c}40 \\
(5.3)\end{array}$ \\
\hline 2 & Product Price & $\begin{array}{c}329 \\
(43.9)\end{array}$ & $\begin{array}{c}328 \\
(43.7)\end{array}$ & $\begin{array}{c}55 \\
(7.3)\end{array}$ & $\begin{array}{c}22 \\
(2.9)\end{array}$ & $\begin{array}{c}16 \\
(2.1)\end{array}$ \\
\hline 3 & Officers / Agents are easily locatable & $\begin{array}{c}385 \\
(51.3)\end{array}$ & $\begin{array}{c}184 \\
(24.5)\end{array}$ & $\begin{array}{c}113 \\
(15.1)\end{array}$ & $\begin{array}{c}12 \\
(1.6)\end{array}$ & $\begin{array}{c}56 \\
(7.5)\end{array}$ \\
\hline 4 & Reminder for renewal of policy & $\begin{array}{c}410 \\
(54.7)\end{array}$ & $\begin{array}{c}156 \\
(20.8)\end{array}$ & $\begin{array}{c}104 \\
(13.9)\end{array}$ & $\begin{array}{c}47 \\
(6.3)\end{array}$ & $\begin{array}{c}33 \\
(4.4)\end{array}$ \\
\hline 5 & Response time & $\begin{array}{c}269 \\
(35.9)\end{array}$ & $\begin{array}{c}188 \\
(25.1)\end{array}$ & $\begin{array}{c}167 \\
(22.3)\end{array}$ & $\begin{array}{c}72 \\
(9.6)\end{array}$ & $\begin{array}{c}54 \\
(7.2)\end{array}$ \\
\hline 6 & Speed in Claim settlement & $\begin{array}{c}182 \\
(24.3)\end{array}$ & $\begin{array}{c}227 \\
(30.3)\end{array}$ & $\begin{array}{c}176 \\
(23.5)\end{array}$ & $\begin{array}{c}114 \\
(15.2)\end{array}$ & $\begin{array}{c}51 \\
(6.8)\end{array}$ \\
\hline 7 & Knowledge of the person dealing with you & $\begin{array}{c}173 \\
(23.1)\end{array}$ & $\begin{array}{c}283 \\
(37.7)\end{array}$ & $\begin{array}{c}143 \\
(19.1)\end{array}$ & $\begin{array}{c}120 \\
(16.0)\end{array}$ & $\begin{array}{c}31 \\
(4.1)\end{array}$ \\
\hline 8 & Product type & $\begin{array}{c}177 \\
(23.6)\end{array}$ & $\begin{array}{c}136 \\
(18.1)\end{array}$ & $\begin{array}{c}180 \\
(24.0)\end{array}$ & $\begin{array}{c}151 \\
(20.1)\end{array}$ & $\begin{array}{c}106 \\
(14.1)\end{array}$ \\
\hline 9 & Attitude of Surveyor & $\begin{array}{c}224 \\
(29.9)\end{array}$ & $\begin{array}{c}217 \\
(28.9)\end{array}$ & $\begin{array}{c}107 \\
(14.3)\end{array}$ & $\begin{array}{c}94 \\
(12.5)\end{array}$ & $\begin{array}{c}108 \\
(14.4)\end{array}$ \\
\hline 10 & Office appearance & $\begin{array}{c}131 \\
(17.5)\end{array}$ & $\begin{array}{c}208 \\
(27.7)\end{array}$ & $\begin{array}{c}215 \\
(28.7)\end{array}$ & $\begin{array}{c}119 \\
(15.9)\end{array}$ & $\begin{array}{c}77 \\
(10.3)\end{array}$ \\
\hline 11 & Motivation given by the officials to buy the policy & $\begin{array}{c}222 \\
(29.6)\end{array}$ & $\begin{array}{c}195 \\
(26.0)\end{array}$ & $\begin{array}{c}150 \\
(20.0)\end{array}$ & $\begin{array}{c}80 \\
(10.7)\end{array}$ & $\begin{array}{c}103 \\
(13.7)\end{array}$ \\
\hline 12 & Guidance / help at the time of purchasing the policy & $\begin{array}{c}206 \\
(27.5) \\
\end{array}$ & $\begin{array}{c}153 \\
(20.4) \\
\end{array}$ & $\begin{array}{c}222 \\
(29.6) \\
\end{array}$ & $\begin{array}{c}118 \\
(15.7) \\
\end{array}$ & $\begin{array}{c}51 \\
(6.8) \\
\end{array}$ \\
\hline 13 & Promptness in issuing the policy & $\begin{array}{c}171 \\
(22.8)\end{array}$ & $\begin{array}{c}267 \\
(35.6)\end{array}$ & $\begin{array}{c}158 \\
(21.1)\end{array}$ & $\begin{array}{c}112 \\
(14.9)\end{array}$ & $\begin{array}{c}42 \\
(5.6)\end{array}$ \\
\hline 14 & $\begin{array}{l}\text { Contacts by the development Officers/Agents after } \\
\text { issuing the policy }\end{array}$ & $\begin{array}{c}282 \\
(37.6)\end{array}$ & $\begin{array}{c}167 \\
(22.3)\end{array}$ & $\begin{array}{c}128 \\
(17.1)\end{array}$ & $\begin{array}{c}102 \\
(13.6)\end{array}$ & $\begin{array}{c}71 \\
(9.5)\end{array}$ \\
\hline 15 & $\begin{array}{l}\text { Development officer's attitude in helping the policy } \\
\text { holder at the time of making claims }\end{array}$ & $\begin{array}{c}139 \\
(18.5)\end{array}$ & $\begin{array}{c}471 \\
(62.8) \\
\end{array}$ & $\begin{array}{c}85 \\
(11.3) \\
\end{array}$ & $\begin{array}{c}45 \\
(6.0) \\
\end{array}$ & $\begin{array}{c}10 \\
(1.3)\end{array}$ \\
\hline 16 & Agent's attitude in guiding the claim settlement & $\begin{array}{c}348 \\
(46.4)\end{array}$ & $\begin{array}{c}229 \\
(30.5)\end{array}$ & $\begin{array}{c}86 \\
(11.5)\end{array}$ & $\begin{array}{c}29 \\
(3.9)\end{array}$ & $\begin{array}{c}58 \\
(7.7)\end{array}$ \\
\hline 17 & Company's attitude in settling claims & $\begin{array}{c}247 \\
(32.9)\end{array}$ & $\begin{array}{c}175 \\
(23.3)\end{array}$ & $\begin{array}{c}154 \\
(20.5)\end{array}$ & $\begin{array}{c}94 \\
(12.5)\end{array}$ & $\begin{array}{c}80 \\
(10.7)\end{array}$ \\
\hline 18 & $\begin{array}{l}\text { Amount settled by the company (relative worth of the } \\
\text { amount) }\end{array}$ & $\begin{array}{c}273 \\
(36.4)\end{array}$ & $\begin{array}{c}224 \\
(29.9)\end{array}$ & $\begin{array}{c}97 \\
(12.9)\end{array}$ & $\begin{array}{c}55 \\
(7.3)\end{array}$ & $\begin{array}{c}101 \\
(13.5)\end{array}$ \\
\hline 19 & Moral support & $\begin{array}{c}334 \\
(44.5)\end{array}$ & $\begin{array}{c}233 \\
(31.1)\end{array}$ & $\begin{array}{c}111 \\
(14.8)\end{array}$ & $\begin{array}{c}36 \\
(4.8)\end{array}$ & $\begin{array}{c}36 \\
(4.8)\end{array}$ \\
\hline 20 & Bonus for next premium payment & $\begin{array}{c}154 \\
(20.5)\end{array}$ & $\begin{array}{c}175 \\
(23.3)\end{array}$ & $\begin{array}{c}209 \\
(27.9)\end{array}$ & $\begin{array}{c}146 \\
(19.5)\end{array}$ & $\begin{array}{c}66 \\
(8.8)\end{array}$ \\
\hline 21 & Convenient Service & $\begin{array}{c}281 \\
(37.5) \\
\end{array}$ & $\begin{array}{c}208 \\
(27.7) \\
\end{array}$ & $\begin{array}{c}109 \\
(14.5)\end{array}$ & $\begin{array}{c}88 \\
(11.7) \\
\end{array}$ & $\begin{array}{c}64 \\
(8.5) \\
\end{array}$ \\
\hline 22 & Transparent of the Policies & 342 & 209 & 107 & 53 & 39 \\
\hline
\end{tabular}


Customers' Attitude Towards General Insurance - A Factor Analysis Approach

\begin{tabular}{|c|l|c|c|c|c|c|}
\hline \hline S.No. & \multicolumn{1}{|c|}{ Factors } & HS & S & N & DS & HDS \\
\hline & & $(45.6)$ & $(27.9)$ & $(14.3)$ & $(7.1)$ & $(5.2)$ \\
\hline \multirow{2}{*}{23} & Claim Settlement Percentage & 162 & 201 & 164 & 139 & 84 \\
& & $(21.6)$ & $(26.8)$ & $(21.9)$ & $(18.5)$ & $(11.2)$ \\
\hline \multirow{2}{*}{24} & Benefits associated with policy & 229 & 159 & 143 & 121 & 98 \\
& & $(30.5)$ & $(21.2)$ & $(19.1)$ & $(16.1)$ & $(13.1)$ \\
\hline \multirow{2}{*}{25} & Cover more services & 123 & 128 & 204 & 153 & 142 \\
& & $(16.4)$ & $(17.1)$ & $(27.2)$ & $(20.4)$ & $(18.9)$ \\
\hline
\end{tabular}

It is clear from the Table 3 that the respondents are highly satisfied towards the factors like product price, Officers / Agents are easily locatable, Reminder for renewal of policy, Response time, Attitude of Surveyor, Motivation given by the officials to buy the policy, Contacts by the development Officers/Agents after issuing the policy, Agent's attitude in guiding the claim settlement, Company's attitude in settling claims, Amount settled by the company (relative worth of the amount), Moral support, Convenient Service, Transparent of the Policies and Benefits associated with policy as 43.9, 51.3, 54.7, 35.9, 29.9, 29.6, 37.6, 46.4, 32.9, 36.4, 44.5, 37.5, 45.6 and 30.5 per cent respectively. The respondents are satisfied towards the factors like, Courtesy of staff, Speed in Claim settlement, Knowledge of the person dealing with you, Promptness in issuing the policy, Development officer's attitude in helping the policy holder at the time of making claims and Claim Settlement Percentage as 40.7, 30.3, 37.7, 35.6, 62.8 and 26.8 per cent respectively. The respondents are neutral towards the factors like product type, office appearance, Guidance / help at the time of purchasing the policy, Bonus for next premium payment and Cover more services as 24.0, 28.7, 29.6, 27.9 and 27.6 per cent respectively. It is found from the analysis that majority $(62.8 \%)$ respondents are satisfied towards development officer's attitude in helping the policy holder at the time of making claims in general insurance policy. From the above study can be predicted that the above satisfying factors induce the policy holders to purchase the policies in general insurance.

\section{Conclusion}

The competitive climate in the Indian insurance market has changed dramatically over the last one decade. At the same time, changes have been taking place in the government regulations and technology. The expectation of customers is also changing. The existing General Insurance companies have to introduce many new products in the market which have competitive advantage over the products of Private Insurance. The Private Insurance companies have introduced some new innovative services to attract the customers by offering more bonus facilities and attractive services.

It is high time that strategies were chalked out so as to tackle customer service issues before it is too late. The General Insurance sector is expanding and big international players are entering into the arena. The New Private Insurance Companies are consolidating themselves and innovating new methods of customer delight. Among all human relations in service-oriented industry, which is the vital force to run or ruin any organization. Instead of confrontational attitude, it is wise for both to understand each other to the maximum possible extent so as to establish a permanent soothing relationship. This is possible only when both understand their duties. This research is a rewarding exercise to the researcher. The researcher will be delighted if the suggestions are implemented by the Public and Private General Insurance companies.

\section{Suggestions.}

On the basis of the research undertaken, the following recommendations can be made :

1) The General Insurance Companies in the study area should concentrate towards young and middle aged customers and establish a good relationship by providing an attractive service. Since the young respondents' relationship with the insurance can be longer due to their age factor, simultaneously the middle aged respondents create a good relationship properly whenever they approach to avail their services in the selected General Insurance Companies.

2) The respondents have received the detailed information of the General Insurance through their advertisement and company agents / officers. Hence, it is suggested that the General Insurance companies may give a wide service in the customers and maintain the attractive advertisement through television (local channel), wall painting and radio (F.M). By doing so, more number of people may be aware of the services and utilize the service of General Insurance.

3) The General Insurance companies, should gives the proper intimation of the renewal of policies and giving proper response of company officials and agents for avoid making false promises and misleading information to the customers in terms of premium amounts, due date and bonus facility. 
4) Even though insurance companies have customer service sections and grievance redressal officers, they have not got the desired attention. These sections were created mainly due to the fact that the formalities are to be complied with as per the guidelines of Government of India instructions. These sections have to be rejuvenated and given due importance.

5) Number of policies: It is highly recommended that the Company has to devise plans to increase the number of policies in case of personal accident and Personal accident schemes in order to spread the schemes to the target customers at the expected rate.

6) Premium Growth: It is also highly recommended that the Company has to devise the strategies to increase the premium growth rate over the target growth rate in case of Personal accident and Workmen's compensation schemes, since the actual growth was not significant.

7) The Target achievement rate was not significant in case of medical and Personal accident schemes and there was poor rate in case of Personal Accident and Workmen's compensation schemes. Therefore, the company has to concentrate on this in the future years.

8) Focus on the schemes: The general insurance companies have concentrated mainly on personal accident and Mediclaim scheme for the three years. Since the premium income under these two schemes constitutes more than $85 \%$ of the total premium income for all the four schemes, it is recommended that the company need to focus its attention on the other two schemes, namely, Personal Accident and Workmen's Compensation schemes in the implementation process in order to have balanced premium income in the sphere of health insurance.

\section{Limitations Of The Study}

There were some limitations in doing this research. This research has been a single-handed effort on the part of the researcher, and certain discrepancies might have occurred owing to the lack of specialized knowledge on this subject. The analysis based on the questionnaire only covers policy holders residing in Erode district and also the sample is relatively small compared to the entire population.

\section{References}

[1] Insurance Principles and Practice M.N. Mishra, S.Chand \& Company Ltd. Ram Nagar, New Delhi, 2004. p.3.

[2] Southern Economist - March 12004 . Vol 42.

[3] Gobi S. and Parthasarathy R, "Selected health insurance schemes in India", Asian Journal of Research in Social Sciences and Humanities, Year : 2011, Volume : 1, Issue : 4, pp.31-40.

[4] Michielsen, Joris; Criel, Bart; Devadasan, Narayanan; Soors, Werner; Wouters, Edwin; Meulemans, Herman, "Can health insurance improve access to quality care for the Indian poor?", International Journal for Quality in Health Care, Volume 23, Number 4, 13 August 2011 ,pp. 471-486(16).

[5] Rohit Kumar, K. Rangarajan and Nagarajan Ranganathan, "Health Insurance in India-A Study of Provider's Perceptions in Delhi \& the NCR", Journal of Health Management September 2011 vol. 13 no. 3 259-277.

[6] Sharma Aparajita, "Managerial Competencies For Middle-level Managers of General Insurance Sector In India", A Journal of Decision Making, Year : 2011, Volume : 11, Issue : 1, pp.27-39.

[7] Tarek Abd Elhamid Ahmed Taha, Yusnidah Ibrahim and Mohd Sobri Minai, "Forecasting general insurance loss reserves in Egypt", African Journal of Business Management Vol. 5(22), pp. 8961-8970, 30 September, 2011.

[8] Pascale Turquet, "Health insurance system financing reforms in the Netherlands, Germany and France: Repercussions for coverage and redistribution?", International Social Security Review, Volume 65, Issue 1, pages 29-51, January-March 2012

[9] Srivastava, Samir K. and Ray, Avishek, Benchmarking Indian General Insurance Firms (October 8, 2011). Benchmarking: an International Journal, 2012. Available at SSRN: http://ssrn.com/ abstract=1968871.

[10] Sukumar Vellakkal,, Financial Protection in Health Insurance Schemes: A Comparative Analysis of Mediclaim Policy and CHAT Scheme in India", Journal of Health Management March 2012 vol. 14 no. 1 13-25.

[11] Vipin Saxena, Deepa Raj, and Vishal Verma, "Vehicle Insurance Policy System through UML”, International Journal of Computer and Electrical Engineering, Vol.4, No.1, January 2012.

[12] Chennappa, D. (2006), "Result of Liberalized India's Insurance Sector : Challenges and Opportunities", The ICFAI Journal of Risk and Insurance. Vol. III, No.3, July, pp. 65-75.

[13] Easwaran, P. S. (2007), "Growth of Indian Insurance Industry after opening up to Private Sector", The Insurance Times, November, pp. 19-21.

[14] Ramana, B. V. (2007), "Insurance Regulator: The Emerging Challenges", Insurance Chronicle, October, pp. 17-23.

[15] Sinha, R. P. (2007), "Productivity and Efficiency of Indian General Insurance Industry", The ICFAI Journal of Risk and Insurance, Vol. IV, No.2, April, pp. 33-43. 